\title{
Image and Global Resemblance in the Light of Hadith "Who So Imitates other People Becomes One of Them"
}

\author{
SERDAR DEMIREL ${ }^{1}$
}

\begin{abstract}
In today's world, people from different countries, cities and institutions unprecedentedly resemble each other in every aspect of life. Likewise, the deeds and imagery aspirations of Oriental and Occidental people also resemble. In such an atmosphere, the local cultures rooted in history become accessories and lose their historical significance and metaphysical aspects in the edifice of the society. This study aims to analyze Prophet Muhammad's (s.a.w.) warning, "Who so imitates other people becomes one of them", its layers of meaning and its relationship with "image and global resemblence".
\end{abstract}

Keywords: culture, image, imitation, globalization, hadith, tashabbuh

Today, we are going through a period when people from different countries, cities and institutions unprecedentedly resemble each other. Resemblance emerges as a magnifying phenomenon in every aspect of life. For instance, from East to West, from North to South, urbanization homogenizes in the mould of a West-centred context of culture and urban people resemble each other in socio-economic and socio-cultural aspects. In other words, cities have their own identities depending on man. Man reflects his perception of the universe and his sustaining belief of metaphysics on the cities he constructs. The aesthetic qualities of the structures of cities are the realization of this perception. A city is a living materialization of the spirit of a society, its perception of life and religion. Thus, a city is never constructed irrespective of the spiritual worlds, cultural perceptions or edifices of its dwellers. In brief, a city reflects the edifice of its dwellers as the dwellers reflect their worldviews in cities.

Classical, ancient structures of cities are greatly varied in aesthetic regard, and they all reflect different worldviews through the cities I have visited extending from Europe to Far Asia. Nevertheless, today we witness that these cities are abandoned, turned into historical heritage sites as people flood into the metropolis. We also unfortunately witness that all metropolis extending from America to Europe, or from the Middle East to the Far East show a uniformed structure.

Likewise, the deeds and imagery aspirations of Oriental and Occidental people also resemble. In such an atmosphere, the local cultures rooted in history become accessories and lose their historical significance and metaphysical aspects in the edifice of the society because classic architecture is a product of rich cultures, while modern cities are the design of a world of engineering. As modern architecture is a perception of secular Western edifice, its cities are constructed in a similar uniformed structural identity. This destroys cultural richness of different civilizations and enriches the orchestrators of modern architecture.

The reform packages offered by Western countries for the sake of modernization eradicate the differences between ancient cultures, traditions and human experiences in a socio-cultural sense and standardize the world. In this regard, Ali Bulac (2011) warns that:

\footnotetext{
${ }^{1}$ Serdar Demirel, Ph.D., associate professor at Faculty of Islamic Sciences, Fatih Sultan Mehmet Vakıf University, Zeyrek Mah., Büyükkaraman Cad. No:53, 34080 FATIH, İstanbul, Turkey, email: serdard22@hotmail.com,sdemirel@fsm.edu.tr.
} 
Structures following the model of modern Western urbanization and the structures which emerge as a result of projects or urban transformation are exact similitude. Twin cities are emerging everywhere in the world. On one side lies the diverse ancient cities of various civilizations and cultures, continuously being abandoned and derelict, and on the other are the modern, Western models of urbanization based on vertical and drawn up structure.

This monotypic structuralization is undoubtedly the greatest achievement of the West. The global conquest, unachievable through battles, has been accomplished through cultural assimilation. What is touted as "integration with the world" or "global citizenship" is indeed succumbing to Western codes of civilization. In the age of modernization, our minds are obscured by such slogans which condemn its opponents because of their promoted positive connotations. Homogenization within the boundaries of ontological edifices and their representations in life pose a paradox in the modern age when "multiculturalism" is widely discussed. In this regard, this study aims to analyze Prophet Muhammad's (s.a.w.) warning "Who so imitates other people becomes one of them", its layers of meaning and its relationship with "image and global resemblence".

\section{The Framework of Meaning Laid out by the Hadith}

First, it should be stated that according to ulum al-hadith (hadith sciences) the hadith "Who so imitates other people becomes one of them" (Abu Dawud n.d. 4: 44, hadith no. 4031) is acceptable to be practised. This hadith is mashur (well-known) through the narration of Abu Dawud through Ibn Omar. The same hadith was narrated in various ways by Huzayfah b. alYaman (al-Tabarani 1415H, 8: 179), Abu Hurayrah and Anas b. Malik (al-Zayl ai. 1997: 4: 347). There are also other shawahed (supporting) narrations such as "Whoever imitates a people other than us is not one of us". (al-Tirmidhi. n.d. 5: 56; al-Tabarani 1415H, 7: 238).

According to ulum al-hadith, maqbul (accepted) hadith is a type of hadith which is practised upon and used as proof in jurisprudence. Maqbul hadith has two categories: sahih and hasan. Some scholars say that this hadith is maqbul in the degree of sahih, (al-Bani 1985, 5: 109; al-San`ani 1960, 4: 175), while some categorize it as hasan (Ibn Hajar al-`Asqalani n.d. 10: 271).

In this hadith, the Prophet (s.a.w.) prohibited emulating cultures representing religions other than Islam and resembling the followers of these religions and cultures. As it was stated earlier, the main topic of this article is 'resemblance' and therefore 'resemblance' should be defined in linguistic and jurisprudential aspects.

In Arabic, the word 'resemblance' is derived from the root 'shibh, shebeh, or shabih', which means equal or similar (Ibn Manzur n.d. 13: 503). The word 'ashbaha' which is derived from the same root means to resemble while the word 'tashabbaha' which occurs in the hadith means to 'try to resemble'. The difference between the two verbs lies in the bab (section) of 'tashabbuh' which attributes the meaning of 'taqalluf (artificialness, trying) (Ibn al-Hajib 1995: 20 ) and as such, the verb 'tashabbaha' should also carry the meaning of a deliberate attempt to resemble.

In their analysis of this hadith, Islamic studies scholars maintain that the prohibited kind of resemblance is in terms of ethical stance, demeanour, deeds, clothing, etc. (Ibn 'Abd al-Bir n.d, 6:80; al-'Azim Abady 1968, 9: 1036). In this regard, they state that resembling steadfast believers is acceptable and following unbelievers and sinners is condemnable (al- Azim Abadi 1968, 9: 1036).

Sheikh al-Munawi (1994: 6: 135) narrates that some scholars said: "Resembling others can sometimes occur in abstract issues such as faith and willingness/ deliberateness while sometimes it occurs in material issues such as speech, deeds, food, clothing, marriage, gatherings, travelling, settlements, transportation, etc". In Islamic worldview, seen and unseen, 
internal and external are closely related. Allah (s.w.t.) sent Prophet Muhammad (s.a.w.) with hikmah (wisdom) materialized in his sunnah and it was why Allah (s.w.t.) assigned him as shir'a and minhaj. In this regard, there are deeds and sayings assigned to the Prophet (s.a.w.) which distinguish his way from those who went astray and those who were condemned. In this hadith, Allah (s.w.t.) ordered the Prophet (s.a.w.) to distinguish himself from those people. Even though He did not designate any rules (for resemblance in appearance per se), He ordered such distinction. Any resemblance in appearance would result in compatibility and similarity between the parties which resemble each other. Such resemblance inevitably would result in similarities between codes of ethics and practice.

The crux of the interpretations of Muslim scholars on this hadith is the preservation of unique identities of Muslim individuals and societies because the inner world, unknown to others, and its representation in the outer world are closely related. In this manner, the hadith narated by al-Nu'man bin Bashir (al-Bukhari 1987, 1: 20, hadith no. 52; Muslim, n.d. 5: 50, hadith no. 4178) below is significant to comprehend that our edifice affects and shapes the outer world:

There is a piece of flesh in the body. If it is healthy, the whole body is healthy. If it becomes unhealthy, the whole body becomes unhealthy, beware! That is the heart.

This hadith clearly states that what is halal and haram; there are, however, suspected elements (mutashabihat) in between and one who protects himself from such things will also protect his deen. This explains the relationship between actions and the heart. The Prophet (s.a.w.) also informed us that when resemblences not approved by Islamic jurisprudence become rampant in socities, Muslims will come to the brink of huge crises (al-Bukhari, 4: 206, hadith no. 3456; Muslim. vol. 8: 57, hadith no. 6952; Ibn Ḥanbal, 3: 84):

You will follow the wrong ways, of your predecessors so completely and literally that if they should go into the hole of a mastigure, you too will go there." We said, "O Allah's Apostle! Do you mean the Jews and the Christians?" He replied, "Whom else?" (Meaning, of course, the Jews and the Christians).

This hadith informs us of the extent that resemblance to non-Muslims might reach and it what aspects it might occur. The hadith not only informs us of the future but also serves as a warning. The negative consequences of resemblance and its extent are exemplified in the current identity problems of Muslims. We shall elaborate further on this remark.

\section{Image and Alienation Crises}

'Image' and 'emulation' concepts, seeking images and resemblance are intertwined issues, and they have to be tackled together. Image means what is visible, the phenomena of seeing or understanding, its impact on the mind and the formation of a feeling in someone's mind. Its relationship with resemblance is the inner and outer emulation of an image, the desire and the practice of becoming 'the other'.

Another issue which is rampantly observed among Muslims is the lack of reluctance to the internalization of Western life style which emerges as a result of different historical experiences and subjective worldviews. The Western model is not compatible with the Muslim edifice and takes us to a point which renders us neither "us" nor "them". As a result, individuals and societies experience mental disintegration. As a result of the illusion that modernism is a universal process, Western theses, lifestyles, consumption habits, celebrations, etc. are embraced willingly on the premise that they are founded on human nature irrespective of the 
Orient or the Occident. Nevertheless, different civilizations and religions have their own unique lifestyles, consumption habits and aesthetic perceptions as well as their unique artistic activities as reflections of the intricacies of these perceptions. For example, the question of "what is beautiful" has different answers in different cultures and its artistic reflections are in line with such varying perceptions.

In this regard, it is interesting that the artistic reflections of the human role model in ancient Chinese and Indian traditions differ greatly from that of the West. In its human figures, Eastern cultures prioritize wisdom, gnome and inner beauty instead of muscularity accepted by Western counterparts. Since Modern classical Western art focuses on outer beauty, it emphasizes man with "utmost physical perfection". On the contrary, in Eastern cultures, figures which would be considered physically deficit such as short and fat, and most of the time old and long-bearded men are brought forward deliberately. This choice highlights the wisdom, gnosis and inner beauty of man rather than his bodily perfection.

As each civilization has a different conception of existence and time, existence and space, and existence and order, the edifice, as the orbit of their lives, also differs. It lays out their identity and meaning of their existence. However, globalisation manifests a threat against the diversity of civilizations from globalization and it serves as a nihilist manipulation of the secular Western civilization against 'the other'.

In modern times, we see that in all cultures extending from East to West the conceptions of existence and time, existence and space, and existence and order become the same and thus, the perceptions of beauty and aesthetic and their reflections in practical life also become the same in a dangerous way. There is a reason why we regard this situation dangerous. It is a sociological phenomenon that weak individuals and societies imitate those they regard to be stronger. It is not mere imitation because the transformation of individuals, societies from one culture to another and their ideological transformations in the later stages and their alienation also take place in this plane. It is well-known that imitating appearances results in acceptance of ideological inclinations in line with such imitation. Thus, it should not be regarded as a simple matter of choice. When this issue is viewed from this perspective, it is clearly seen that the Prophet's statement "Who so imitates other people becomes one of them" is not a simple warning. Confining this statement to its literary meaning and mere form would be reducing its profound meaning. First and foremost, this statement warns us to preserve our fundamental mind codes which determine our lives and prohibit resemblence of our Muslim mind codes to non-Muslim ones because our lifestyle embraces all aspects of our lives including appearance and eating habits as natural reflexes of our mind codes. Whatever we hold inside can somehow leak outside. If a foreign style did not arouse admiration, it would not be emulated.

In this regard, Muhammad Asad (1999: 69) maintains that imitating the Western lifestyle at individual and society levels is a serious danger, "The imitation -indivudually and socially - of the Western mode of life by Muslims is undoubtedly the greatest danger for the existence or rather the revival of Islamic civilisation.". Calling this attitude sick, Asad (1999: 71) says what we call civilization is not a hollow form but a living energy and when we acknowledge this form, the dynamic effect of the civilization will start penetrating our identities and mind codes. Asad says that the hadith "Who so imitates other people becomes one of them" is a great warning pointing at the alienation effect and highlights that accepting the intellectual and aesthetic arguments of a civilization cannot occur without admiring/adopting its spirit. It is obvious that embracing this foreign civilization with its core against Islamic edifice will affect our identity as Muslims. According to Asad (1999:73):

It is practically impossible to imitate a foreign civilsation in its intellectual and aesthetic design without appreciating its spirit. And it is equally impossible to appreciate the spirit of a civilisation which is opposed to a religious outlook on life and yet to remain a good Muslim. 
Imitation does not occur in a vacuum, instead it stems from admiration and appreciation of images foreign to the 'self' because we ascribe aesthetic and power to those images. By doing so, we empower those images. The process starting with imitation inevitably shapes our edifice and our daily practices and shakes their grounds; as a result, we become culturally alienated. Our pursuit after an image sets our psycho-intellectual parameters which ,in return, determine our actions.

The prohibition of the Prophet (s.a.w.) against emulating the 'other' in religious and cultural sense prohibits intellectual emulation in the first place. Thus, I believe that this hadith describes the essential core of the current 'otherization' crisis. It is obvious that the opposite direction of this prohibition offers the solution to this problem. In other words, this hadith highlights the significance of freeing Muslims of the disease of imitatation and creating a unique Muslim edifice.

\section{The Role of Modern Psychology in Determining Our Choices of Image}

The modern discipline of psychology does not only make objective observations on human psyche. Its observations are rather used to manipulate human behaviour. Understanding how man sets his mind codes and how these codes determine his behaviour is very crucial to understanding the choices of modern man. The meaning of modern man's reflexes cannot be fully grasped without a true understanding of modern psychology because it would be naive to deny the role of education, media, the Internet and cinema in forming individual and social reflexes and claiming that these reflexes develop on their own. The principles of modern psychology, its dynamics and its priorities in manipulations of its findings are shaped according to modern secular Western edifice. Utilization of these findings in line with the Western perception of man and universe is not ethical, but rational. We can summarize the main principles and prerequirements of this worldview below:

1. The Western worldview strips man of the sacred.

2. The West idealizes its civilization and ancient Greek's as its foundational civilizations. It starts its history of civilization with ancient Greek and carries it to the present with modernity. Civilization has one cradle: the West. Surprisingly, it does not read civilization in this way by 'othernizing' only Muslims, Chinese, Hindus or other nonWestern civilizations but also overlooks Europe in Middle Ages.

3. It regards man as an "intellectual animal". It is evident that with his theory of evolution, Darwin was making an attempt to prove that mankind comes from animals in the name of science.

4. Instead of theocentric edifice, it has built humancentric profane edifice. It attributes man's divine qualities and denies the confining authorithy of metaphysical powers above man, God, tradition, etc. Homosexuals claiming "I have the right to use my body as I like" lay the foundation of their claims on this principle of modernity.

5. It defends the supremacy of the white man. This theory depends on the assumption of evolution from monkey to black man and from black man to white man. Thus, white man represents the last stage of evolution. As a result, while the white man is the supreme product of evolution, black man represents the premordial being.

6. It entrenches the absoluteness of science. While denying that revelation containes absolute truth, it elevates the human product and experience to an unquestionable level and renders it sacred. By regarding its findings and interpretations scientific, the lifestyle and choices proposed by the West are also imposed as scientific. 
The cause-effect relationship of intra-civilizational arguments between image, imitation and resemblence is very strong. In our globalised world, the inclination to act irrespective of the sacred and idealization of the Western culture, promotion of the animal aspect of man at the expense of his human aspect, human-centricism, and the idealization of the Western white man by all ethnicities extending from Japanese and Chinese to Indian and Turkish and acceptance of the choices of modernity as scientific choices cannot be read separately from the main principles of modern psychology and imposition of states based on these principles. This inevitably results in a paradox of paradigms for children of different civilizations.

Persian thinker Daryush Shayegan asserts that "non-Western civilizations experience two paradigms; their paradigm and the paradigm stemming from big scientific revolutions (modern episteme in Foucauldian terms). How can man, living in a world of two clashing paradigms, accept this situation without facing the risk of exhibiting unruly behaviour? How can he block the waves hitting him all around? The clash of two paradigms is the foundation of ontological, psychological as well as aesthetic disparities and paradox of tradition and modernity" (Shayegan 2007: 59).

The statement of Hazrat Huzayfa (r.a.), one of the Prophet's (s.a.w.) companions “ appearances won't be alike unless moralities are alike" and Ibn Mas'ud's (r.a.) opinion that "appearances won't be alike unless hearts are alike" crystallize this paradox. These simple yet profound contentions about unity of soul-body, and internal-external worlds notify that material culture cannot be regarded separately from spiritual culture.

\section{Image and Ikhlas}

Ikhlas is a metaphysical dimension which acts as the propelling force of our actions and an inherent component of our intentions. In other words, it is the effort of gaining the content of Allah (s.w.t.) in our actions. Ikhlas can be considered a state of the heart, an exalted state attained with sincere, pure love and devotion and a spiritual asset which increases with closenes to Allah (s.w.t.) and truth and decreases with distance. Being a true mukhlis is only attainable by utmost submission to Allah's will. Ikhlas can also be described as purification of the heart from spite and suspicion. Virtual, on the other hand, is used to refer to the Latinoriginated word 'simulation'. Virtual/simulation refers to acting or feeling as if something exists. The virtual world is reflected in postmodern culture and it is the dimension in which reality is reduced to visual. In virtuality, meaning is effaced in and reduced to vision. Visuality obscures an image-based world and substitutes it for reality.

People of the digital era experience virtuality more intensely than the surrounding reality. Virtuality and reality have swapped places, and in such a world, Islamic sentiments become virtual. In order to restore the feeling of being a Muslim, man has to reach out to the reality presiding outside the virtual realm. Caressing an orphan's head, for instance, cannot be done virtually.

While people chase fake images in a virtual world, ikhlas, a crucial concept in Islam, gradually loses its meaning. Ikhlas pertains to a pure and innocent heart and the heart reaches this state only when it is cleansed of complexities. Only a man with a pure and innocent heart can perform pure and innocent acts. The judgement of actions according to intentions is also related to this principle. The biggest plot of Iblis is to taint intentions with arrogance, vanity and other vices. The effort to be 'visible' in behaviour patterns of the modern world is a virus infecting intenions and it thrives on the 'image idol' of the virtual world. Nevertheless, the Prophet (s.a.w.) warned his ummah about the crucial role of ikhlas (al-Bukhari 1987, 1: 2, hadith no. 1): 
Actions are (judged) by motives (niyyah), so each man will have what he intended. So whoever emigrated for worldly benefits or for a woman to marry, his emigration was for what he emigrated for.

Imam Bukhari chose this hadith as the first hadith of the first chapter of his Sahih. The first chapter, however, has no direct relevance to this hadith because this chapter, Kitab alWahy, contains ahadith on the issue of wahy (revelation). By doing so, Imam Bukhari wanted to highlight that intentions and ikhlas constitute the core of religion. It is evident that seeking images and the trend of imitation as a form of appreciation of such images pose a great threat to ikhlas. According to Islam, there is a thin line between worship and tradition as both denote habitual social actions. Only an intention distinguishes an act of tradition from worship. The materializing force of profane images notes another layer of meaning for the hadith of tashabbuh.

As a conclusion, accepting profane images and seeking superiority in these images are global phenomena today. It is evident that man is affected by his environment and he is exposed to social pressure when he is at the young ages of constructing their worldview.

This situation marks a divergence from what is noted by the verse, "Ye must gain mastery if ye are true in Faith" (al-Quran, Ali 'Imran, 3:139). The responsibility of not resembling someone else and the foundation of the meaning highlighted by this hadith lie in the preservation of superiority of Muslims due to their adherence to their innate values. However, if the situation in the Muslim world is the opposite of that as delineated by the Prophet (s.a.w.), then we should emphasize that it is not an Islamic way.

It seems that 'if you can't destroy something you should make it resemble you' strategy of orientalism is a vanguard of colonialism. The Muslim mind is being "deconstructed" through images and imitations and thus orientalises and colonizes itself. The claim that there in no symbolic relationship between behaviours and values is difficult to accept in light of the aforementioned explanation on social psyche. It is commonly agreed that our cities, relationships, construction and conveyance of our thoughts, sources of reference, favourite movies, artists, football teams, body language and perception of men and women are largely Westernized.

An important dimension of imitating the West is economic. The economic reform packaged devised by the West maintains the welfare, wealth and military hegemony of the West while rendering the East mere consumers. The West grows richer as the East consumes its products. Unless non-Western countries digest these reforms and change their socio-economic, administrative and political structures accordingly, the West will face great challenges in sustaining its current superiority. Another important issue is not comprehending the difference between living in a modern age and being modern. Today, we all live in a modern era, but this does not require surrendering to profane modern values.

Due to not discerning between the two, the way to prestige is deemed to be imitating the images alien to our civilization. Man internalizes the consuming habits of whom he wishes to imitate to attain his goals. In this regard, although modern man deems himself to be free, he cannot be considered free. Modern man's consumption habits are controlled by the rich elites, advertisers, and fashion designers and his choices are not free anymore. This is the main source of power which keeps capitalism alive. This process plays with man's understanding of reality and alters it. All these point at the deep layers of the meaning of this hadith.

\section{References}

al-`Azim Abadi, Muhammad Shams al-Haq. 1968. 'Awn al-Ma'bud Sharh Sunan Abi Dawud. 2nd ed. `Abd al-Rahman Muhammad 'Uthman (ed.). Al-Madinah: al-Maktabah al-Salafyyah.

Albani, Muhammad Nasr al-Din. 1985. Irwa' al-Ghalil fi Takhrij Ahadith Manar al-Sabil. $2^{\text {nd }}$ ed. Beirut: al-Maktabah al-Islami. 
Abu Dawud, Sulayman bin al-Ash'ath. n.d Sunan Abi Dawud (ed.). Muhammad Muhy al-Din `Abd al-Hamid. n.l.: Dar al-Fikr.

Asad, Muhammad. 1999. Islam at the Crossroads. Kuala Lumpur: The Other Press.

al-Bukhari, Muhammad bin Isma il. 1987. Sahih al-Bukhari. $1^{\text {st }}$ ed. Cairo: Dar al-Shab.

Bulaç, Ali. 2011. "Kendimiz değişebilir miyiz?" Zaman Gazetesi. <http://www.zaman.com.tr/ yazar.do?yazino=1083367\&title=kendimiz-degisebilir-miyiz >, Retrieved on 20-04-2015.

Davutoğlu, Ahmet. 1997. Medeniyetlerin Ben-idraki. Divan. Istanbul: n.p.

Ibn `Abd al-Bir, Abu `Amr Yusuf bin `Abd Allah. n.d. al-Tamhid Lima fi al-Muwatta` min al-Ma `ani wa al-Asanid. Mustafa bin Ahmad al-`Alwi and Muhammad `Abd al-Kabyr al-Bukra (ed.). n.l: Mu`assasah al-Qurtubah.

Ibn Hajar al-'Asqalani, Ahmad Bin `Ali. n.d. Fath al-Bari Shari Sahih al-Bukhari. Muhammad Fu'ad `Abd al-Baqi and Muhib al-Din al-Khatib (ed.). Beirut: Dar al-Ma`rifah.

Ibn al-Hajib, Jamal al-Din al-Duwayni. 1995. al-Shafih fi ' 'Im al-Tasrif. $1^{\text {st }}$ ed. Hasan Ahmad al'Othman (ed.). Makkah al-Mukarramah: al-Maktabah al-Makiyyah.

Ibn Hanbal, Abu `Abd Allah Ahmad al-Shaybani. n.d. Musnad Ahmad. Egypt: Mu`assasah Qurtubah.

Ibn Manzur, Muhammad bin Mokram. n.d. Lisan al-'Arabi. 1'st ed. Beirut: Dar Sadr.

Ibn Taymiyyah. (n.d). Iqtida al-Sorat al-Mosatqim Lil Mukhalfh Ashab al-Jahim. Nasir `Abdal Karim al-`Aql (ed.). Al-Riyad: Maktabah al-Roshd.

al-Kawthari, Muhammad Zahid. 1372 A.H. Maqalat al-Kawthari. $1^{\text {st }}$ ed. Karachi: Adab Manzil.

al-Munawi, Zayn al-Din Muhammad. 1994. Fayd al-Qadir Sharh al-Jam `al-Saghir. 1st ed. Beirut: Dar al-Kutub al-`Imiyyah.

al-Qushayri, Muslim Bin Hajjaj. n.d. Sahih Muslim. Beirut: Dar al-Jil.

al-San`ani, Muhammad bin Isma`il. 1960. Subul al-Salam. 4th ed. n.l.: Maktabah Mustafa al-Babi al-Halabi.

Shayegan, Daryush. 2007. Yaralı Bilinç Geleneksel Toplumlarda Kültürel Şizofreni. 5 ed. İstanbul: Metis Yayınları.

al-Tabarani, Sulaman bin Ahmad.1415 A.H. al-Mu'jam al-Awsat. Tariq bin `Awd Allah bin Muhammad, `Abd al-Mohsin bin Ibrahim al-Husny (eds.). Cairo: Dar al-Haramin.

al-Tirmidhi, Muhammad Bin 'Isa. n.d. Sunani al-Tirmidhi. Ahmad Muhammad Shakir (ed.). Beirut: Dar Ihya al-Turath al-Arabi.

Toynbee, A.J. 1965. A Study of History. New York: Oxford University Press.

al-Zayl`ai, Jamal al-Din. 1997. Nasb al-Rayah li Ahadith al-Hidayah. $1^{\text {st }}$ ed. Muhammad 'Awamah. (Ed.). Beirut: Muassasah al-Rayyan li al-Tiba`ah wa al-Nashr. 